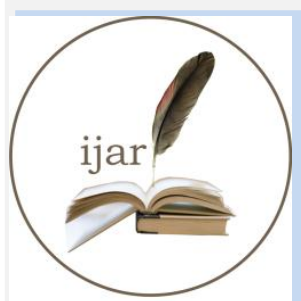

ISSN NO. 2320-5407
Journal Homepage: - www.journalijar.com INTERNATIONAL JOURNAL OF ADVANCED RESEARCH (IJAR)

Article DOI: 10.21474/IJAR01/10241

DOI URL: http://dx.doi.org/10.21474/IJAR01/10241
INTERNATIONAL JOURNAL OF ADVANCED RESEARCH (IJAR)

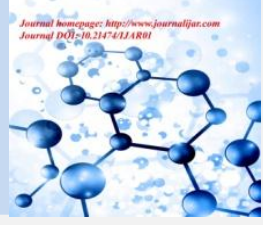

RESEARCH ARTICLE

\title{
HOUSEHOLD PROFILES OF BEEF CATTLE LIVESTOCK IN THE AREA OF TEAK FOREST, BOJONEGORO, EAST JAVA
}

\section{Priyo Sugeng Winarto, Zaenal Fanani, Bambang Ali Nugroho and Ifar Subagiyo}

Animal Science Faculty, Brawijaya University.

\section{Manuscript Info}

\section{Manuscript History}

Received: 12 October 2019

Final Accepted: 14 November 2019

Published: December 2019

\section{Abstract}

The study was conducted in Napis Village, Tambakrejo District, Bojonegoro Regency with the aim of expressing an empirical profile of the indicators of the empowerment of smallholder beef cattle farmers using sustainable livelihoods framework tools. Data collection method used in this study is by interviewing respondents directly. The type of data used in this study are primary and secondary data and analyzed with descriptive analysis. The analysis shows that the majority of farmer households (45\%) maintain 2 to 3 Animal Units (ST). the majority of breeders' education level only graduated elementary school / equivalent of $41.5 \%$ and the average experience of raising beef cattle for 8 years. The 'maro' working relationship (33\%) is adopted by farmers, besides raising a cow of their own (27.5\%). Most (32.5\%) of farmers' households control an area of between 600$1000 \mathrm{~m} 2$. From the research it can be concluded that the sustainable livelihoods of the household of beef cattle farmers is not enough to be stated only by indicators of livelihoods-status consisting of 5 types of capital, namely: (1) Human Capital, (2) Natural Capital, (3) Financial Capital, (4) Physical Capital, and (5) Social Capital only, but it also needs to include the farmer household resilience component and the farmer household dynamism component.

Copy Right, IJAR, 2019,. All rights reserved.

\section{Introduction:-}

The amount of beef needed for food is increasing due to population growth, increased public purchasing power, and increased awareness to meet the need for animal protein to improve the quality of Indonesian human resources.

Note the figures for domestic consumption of beef in 2010 to 2012, respectively, were 418 thousand tons, 450 thousand tons and 510 thousand tons. The supply side of production in the same year range shows 436 thousand tons, 485 thousand tons and 509 thousand tons respectively (Dahiri, 2016). This means that until 2012, the demand for beef for the food needs of the Indonesian people can be met by the production of beef produced by the local beef cattle business community.

However, the balance between the amount of consumption and the amount of domestic beef production has changed since 2013. The amount of beef consumption is more than the amount of beef produced domestically. There is a shortage of beef supply produced by domestic beef cattle farms to meet people's consumption needs. In the span of

\section{Corresponding Author:- Priyo Sugeng Winarto}


2013 to 2015, the number of domestic beef production supply shortages amounted to 45.64 thousand tons, 95.85 thousand tons and 130.05 thousand tons, respectively. Based on the data of the beef supply deficit that is produced domestically, it seems that the number of deficiencies in question tends to increase. Estimates as intended, are confirmed by data on the amount of beef consumption per capita per year of the increasing Indonesian population (Agus and Widi, 2018). In the range from 2010 to 2015, the number of beef consumption is $1.76 \mathrm{~kg} / \mathrm{capita} / \mathrm{year}$; $1.87 \mathrm{~kg} /$ capita / year; $2.09 \mathrm{~kg} /$ capita / year; $2.22 \mathrm{~kg} /$ capita / year; $2.36 \mathrm{~kg}$ / capita / year; and $2.56 \mathrm{~kg} / \mathrm{capita} /$ year in 2015 (Dahiri, 2016).

The development program in the field of beef cattle breeding business through increasing development activities with various approaches aimed at increasing national beef production has been widely implemented. However, it seems that the achievement of beef cattle development activities in the country in the form of increasing the amount of domestic beef production has not been able to catch up with the rate of increasing the amount of beef needed for the consumption needs of the Indonesian people. The problem of being behind the production of beef produced by the domestic livestock business in question, is confirmed by data showing the activities of importing live beef and live cattle from abroad.

Data published in 2016 by the Indonesian Republic of Indonesia's House of Representatives Budget Expertise Assessment Center Center stated that in 2010 Indonesia imported around 140.1 thousand tons of beef and a number of live cattle equivalent to 210.7 thousand tons of meat; so that the overall number of Indonesian imports is 350.8 thousand tons of beef and live cattle equivalent to meat. The total number of imported beef and live cattle equivalent to meat in the range of 2011 to 2014 , sequentially was 225.2 thousand tons in 2011 ; 141.7 thousand tons in 2012 ; 185.3 thousand tons in 2013; and 351.7 thousand tons of beef and live cattle equivalent to meat in 2014 (Dahiri, 2016).

The tendency of an increase in the number of imported beef and live cattle is thought to be caused by a decrease in the number of national beef cattle populations (Rusdiana and Soeharsono, 2017) whose existence is unevenly distributed in the business activities of smallholder beef cattle business carried out by around 5,074,033 households; and from the total national population of the beef cattle breeders, around 2,029,613 units or around $40 \%$ of the national population of the farmers, the farmers are approximately 3,545,500 or about $28.8 \%$ of the national beef cattle population in the rural areas of Java Province East (Central Statistics Agency, 2015). The results of the 2013 Agricultural Census or ST2013 give an indication that the majority of rural beef cattle farmers households in rural areas do not have good enough access to productive resources for the continuation of beef cattle farming activities adequately. Access to productive resources in question includes low access to: (1) people's beef cattle business capital, (2) community beef cattle business institutions, (3) extension activities, and (4) marketing of people's beef cattle products (BPS, 2015). Therefore, beef cattle farmer households require empowerment activities facilitated by the government with the aim of increasing household empowerment. Increased empowerment of beef cattle farmer households is believed to increase the ability of the farmer households concerned to be able to better access productive resources to support beef cattle farming; in turn, the objectives of beef cattle business will increase, in line with the increase in household welfare on an ongoing basis.

Trade agreements between Indonesia and other countries in the regional and international region in the last two decades, have consequences on the nuances of government policies related to the development of beef cattle breeding. One of the desired requirements to occur as a result of the implementation of the said policy is to encourage wider community participation than top-down policy, as well as the free competition mechanism among beef cattle business actors in the country (Mayulu, Sunarso, Sutrisno and Sumarsono, 2010). In the situation of free competition, there are growing concerns about the various forms of vulnerability in more than 5 million households of Indonesian beef cattle breeders; more than that, the people's beef cattle farmer households still have to deal with the adverse effects of climate change on the beef cattle farming business system that is done. The adverse effects of climate change and the increasingly vulnerable condition of household livelihoods due to the pressure of free competition, sooner or later will affect the dynamics of most of the household's beef cattle breeders responded positively to the national program of beef cattle development in Indonesia; in other words, the decline in resilience and dynamism of beef cattle breeders' households will affect the empowerment of most of the rural beef cattle farmers households.

The concept of empowerment seems to have become a kind of big arena in the perspective of efforts to increase the people's economic capacity through current development programs. In fact, the Directorate General of Animal 
Husbandry and Animal Health of the Ministry of Agriculture of the Republic of Indonesia has also initiated various national programs for animal husbandry development by carrying out various agribusiness development activities for beef cattle breeding by making the concept of empowerment a spirit that animates all national programs and activities related to the development of beef cattle agribusiness dual aims are: (1) increasing production, and (2) empowering the community (Diwyanto, Inounu, Setioko, Subandriyo, Kompiang, Parede, Priyanti, Martindah, Saptati, and Nurhayati, 2007).

Furthermore, Boettcher, Mottet, Acosta, and Baumung (FAO, 2018) recommend that national livestock development policies in each country with the aim to: (1) increase livestock production in a sustainable manner and (2) increase efforts to empower people, should be further developed its contribution to sustainable development goals is in line with the substance of The Sustainable Development Goals (SDG's) Livestock Sector, which includes that animal husbandry development must link to activities: (1) poverty eradication, (2) eradication of hunger, (3) improving health and humanitarian status, (4) improving the quality of education, (5) increasing gender equality, (6) providing clean water and environmental sanitation, (7) reducing the adverse effects of climate change, (8) increasing employment and income opportunities, (9) increasing the use of innovation and infrastructure, (10) reducing injustice, (11) conserving resources biological resources, and (12) development of collaborative networks.

Based on the phenomenon of the growing diversity of development approaches and their relationship with development goals, it can be stated that empowerment is a concept of a process of social change which is an important mode for the implementation of development programs and activities. However, indicators and measures other than production and productivity as techniques for expressing the empowerment of households and communities as a result of the process of social change are still relatively underdeveloped; and related to the need for indicators and measures of empowerment, research on household beef cattle farmers in the perspective of the process of social change is carried out. Related to these needs, the formulation of the problem is how the empowerment profile of the beef cattle farmers is expressed using the sustainable livelihood framework tool.

\section{Research Method:-}

\section{Research location and farmer survey sample:}

The research was conducted in Napis Village, Tambakrejo District, Bojonegoro Regency covering 11 hamlets, such as: (1) Napis Hamlet, (2) Dolog Hamlet, (3) Pencol Hamlet, (4) Doplang Hamlet, (5) Daplangu Hamlet, (6) Bagi Hamlet, (7) Windu Hamlet, (8) Koripan Hamlet, (9) Kalidandang Hamlet, (10) Tawaran Hamlet, and (11) Jubleg Hamlet (Figure 4.2). Based on the enumeration, overall there were 1397 households that raised PO cows, no other types of cattle were found. The size of the number of household survey samples is set at $14 \%$ of the population of smallholder beef cattle breeders in Napis Village.

Considering the affordability of the location and the distance between beef cattle farmer's houses to be visited is related to the needs of the survey of household samples of beef cattle breeders and structured interviews guided by questionnaires, then it was determined to use a rolling method (snowball-sampling). Of a population measuring 1397 units of smallholder beef cattle farmer households in eleven hamlets in Napis Village, 200 sample units were recorded for the purposes of household beef cattle breeder household surveys.

\section{Data collection technique}

Data collection method used in this study is by interviewing the respondent directly, another method that is used is a questionnaire with a list of prepared questions given to respondents to obtain answers. Interviews and questionnaires focused on socio-economic conditions of farmers, characteristics of farmers, conditions of the business environment, support of related parties, business characteristics, pentagonal asset data, household resilience and dynamism. Data collection methods in this study are interviews, observation, and documentation.

\section{Data source}

The type of data used in this study are primary and secondary data. Primary data were collected through direct interviews with farmers based on a questionnaire set by the researchers, namely the characteristics of farmers, business characteristics, business environment, livelihood status of the household, and household security and dynamism. Data collected in this way included data from the Animal Husbandry Office of Bojonegoro Regency, BPS of the District of Bojonegoro and the Central BPS. 


\section{Results And Discussion:-}

Characteristics of Small Beef Cattle Farmers:-

Napis Village, Tambakrejo Subdistrict, Bojonegoro Regency had a population of 7588 people in 2018, consisting of around 2023 households, and there were 1397 households as keepers of Ongole Peranakan cattle (PO). There are 200 respondents of beef cattle breeders. The researcher conducted an in-depth interview with the head of the RT family of farmers in Napis village. The description of respondents that will be presented includes the characteristics of smallholder beef cattle breeders (family heads), a description of the composition of the cattle population, and the number and mastery of cattle. The data supports researchers to explain the current conditions that will support the conditions of empowerment of farmers and the factors that influence them. An overview of the characteristics of smallholder beef cattle farmers is presented in table 5.1.

Table 1:- Characteristics of Age, Education and Length of Farming Head of Farmer Households in Napis Village, Tambakrejo District, Bojonegoro.

\begin{tabular}{|c|c|c|c|c|c|}
\hline \multirow{6}{*}{$\begin{array}{l}\text { No. } \\
1 .\end{array}$} & \multirow{6}{*}{\begin{tabular}{|l|} 
Description \\
Age of Farmer KK \\
\end{tabular}} & \multicolumn{2}{|c|}{ Category } & \multirow{2}{*}{$\begin{array}{r}\text { RT } \\
8\end{array}$} & \multirow{2}{*}{$\begin{array}{ll}\%) & \\
& 4,0\end{array}$} \\
\hline & & 1 & $\geq 61$ у.o & & \\
\hline & & 2 & $51--60$ y.o & 36 & 18,0 \\
\hline & & 3 & $41--50$ y.o & 68 & 34,0 \\
\hline & & 4 & $31-40$ y.o & 57 & 28,5 \\
\hline & & 5 & $\leq 30$ y.o & 31 & 15,5 \\
\hline \multirow[t]{5}{*}{2.} & \multirow{5}{*}{$\begin{array}{l}\text { Formal Educational } \\
\text { Achievement of Farmer } \\
\text { Families }\end{array}$} & 1 & Not completed in primary school & 33 & 16,5 \\
\hline & & 2 & Graduated from elementary school or similar & 83 & 41,5 \\
\hline & & 3 & Graduated from junior / junior high school or similar & 69 & 34,5 \\
\hline & & 4 & Graduated from high school / high school or similar & 14 & 7,0 \\
\hline & & 5 & Graduated from an academy / college & 1 & 0,5 \\
\hline \multirow[t]{5}{*}{3.} & \multirow[t]{5}{*}{ Older Cattle Breeding } & 1 & Less than 4 years & 11 & 5,5 \\
\hline & & 2 & 5 years to $<6$ years & 31 & 15,5 \\
\hline & & 3 & 7 years to $<10$ years & 70 & 35,0 \\
\hline & & 4 & 11 years to $<14$ years & 56 & 28,0 \\
\hline & & 5 & $>15$ years & 32 & 16,0 \\
\hline \multirow[t]{5}{*}{4.} & \multirow[t]{5}{*}{ Land area owned } & 1 & Around $200 \mathrm{~m} 2$ & 10 & 5,0 \\
\hline & & 2 & $250 \mathrm{~m}^{2} \mathrm{~s} / \mathrm{d} \leq 500 \mathrm{~m}^{2}$ & 33 & 16,5 \\
\hline & & 3 & $600 \mathrm{~m}^{2} \mathrm{~s} / \mathrm{d} \leq 1000 \mathrm{~m}^{2}$ & 65 & 32,5 \\
\hline & & 4 & $1500 \mathrm{~m}^{2} \mathrm{~s} / \mathrm{d} \leq 2000 \mathrm{~m}^{2}$ & 53 & 26,5 \\
\hline & & 5 & $>2500 \mathrm{~m}^{2}(=0,25$ hektar $)$ & 39 & 19,5 \\
\hline \multirow[t]{5}{*}{5.} & \multirow{5}{*}{$\begin{array}{l}\text { Number of RT } \\
\text { members involved in } \\
\text { the Cattle Business }\end{array}$} & 1 & 1 person only & 3 & 1,5 \\
\hline & & 2 & 2 persons & 46 & 23,0 \\
\hline & & 3 & 3 people & 67 & 33,5 \\
\hline & & 4 & 4 people & 56 & 28,0 \\
\hline & & 5 & $>5$ people & 28 & 14,0 \\
\hline
\end{tabular}

Table 1:- explains that most (34\%) are in the age range of 41-50 years, followed later by farmers between the ages of 31-40 years $(28.5 \%)$. About $56 \%$ of farmers over 40 years old. This condition shows that most of the breeders are old-age breeders, while only around 54\% of breeders are under 40 years old. Theoretically, the adoption of innovations, the target group is old age rather slowly in accepting innovation, there are even some targets that refuse. It is stated in the data that aged farmers (over 51 years) are $22 \%$ higher than young farmers under 30 years by $15.5 \%$. It seems that the phenomenon has developed until now that some young people have not been interested in work as breeders of beef cattle, a rival phenomenon that occurs in agriculture widely.

The formal education of beef cattle breeders is classified into 5 categories namely not graduating from elementary school, completing elementary school, completing junior high school, graduating high school, and graduating academy or university. The data shows that the education level of farmers in Napis village, the largest category is only graduating elementary school / equivalent amounting to $41.5 \%$ and subsequently graduating from junior high 
school / junior high or equivalent of 34.5\%. Farmers in Napis Village with the category of Junior High School / Junior High School and below 92.5\% (7.5\%) are breeders with senior high school education and above.

Table 1 provides information that the experience of farmers in raising beef cattle has been very long. The average length of raising is 8 years. In fact, around $79 \%$ of farmers have experience of raising beef cattle over 7 years. This experience or length of breeding is a strength for farmers in developing their business, but sometimes it is an obstacle in the process of adopting innovation. Farmers who have a lot of experience or who have long been trying for beef cattle sometimes feel that they have enough knowledge and skills so they are not responsive to new technologies. About $21 \%$ of breeders are "new players" who have tried between 4-6 years. They are the ones who must quickly pursue their skills in the business of raising beef cattle to be able to improve their business and improve their families' welfare through raising beef cattle.

\section{Distribution of Cattle Population in Napis Village, Tambakrejo District, Bojonegoro:-}

Breeders in Napis Village generally occupy an area of around 5132 ha. Land that is used for agriculture (including animal husbandry) has relatively no irrigated rice fields, around 381 ha of rain-fed rice fields and around 419 ha of tegal or fields. In fact, around 3380 ha of land is PT PERHUTANI BKPH Napis's land. PT PERHUTANI's land includes Daplangu, Bagi, Kalidandang, Tawaran, and Jubleg hamlets. Some conditions of vegetation in forest areas are not so good in the dry season, but erosion will occur during the rainy season. The average number of rainy days is 124 days per year with an average rainfall of $1239 \mathrm{~mm}$ per year. The highest rainfall occurs in January and the lowest in July. The supporting environment in the form of road facilities is still in moderate condition. Market facilities are in the center of Tambakrejo sub-district which is connected with Napis village with poor road conditions. With all these limitations, it is still appreciated that the population is very interested in beef cattle business. It is seen that about $69.05 \%$ of 2023 households in Napis Village are trying beef cattle. An overview of the composition of the cattle population in Napis Village is presented in Table 5.2.

Table 2:- Descriptions of Cattle Population Composition in Napis Village, Tambakrejo District, Bojonegoro.

\begin{tabular}{|c|c|c|c|c|c|c|c|c|c|}
\hline \multirow[t]{3}{*}{ No. } & \multirow[t]{3}{*}{ Hamlet } & \multirow[t]{3}{*}{$\sum \mathrm{RTG}$} & \multicolumn{6}{|c|}{ Composition of Cows } & \multirow[t]{3}{*}{ Amount } \\
\hline & & & \multicolumn{3}{|c|}{ Male } & \multicolumn{3}{|c|}{ Female } & \\
\hline & & & Calf & Young & Adult & Calf & Young & Adult & \\
\hline 1 & Bagi & 139 & 55 & 19 & 26 & 21 & 43 & 154 & 318 \\
\hline 2 & Dolog & 99 & 34 & 28 & 4 & 17 & 37 & 88 & 208 \\
\hline 3 & Doplang & 146 & 54 & 35 & 16 & 41 & 56 & 137 & 339 \\
\hline 4 & Kalidandang & 166 & 65 & 32 & 13 & 77 & 66 & 186 & 439 \\
\hline 5 & Napis & 123 & 38 & 29 & 9 & 34 & 36 & 93 & 239 \\
\hline 6 & Windu & 99 & 23 & 41 & 4 & 13 & 35 & 97 & 213 \\
\hline 7 & Pencol & 76 & 11 & 13 & 9 & 19 & 22 & 71 & 145 \\
\hline 8 & Tawaran & 176 & 77 & 59 & 11 & 50 & 68 & 178 & 443 \\
\hline 9 & Daplangu & 142 & 75 & 23 & 7 & 29 & 18 & 196 & 348 \\
\hline 10 & Koripan & 151 & 38 & 82 & 19 & 18 & 47 & 116 & 320 \\
\hline \multirow[t]{2}{*}{11} & Jubleg & 80 & 23 & 6 & 1 & 23 & 8 & 97 & 158 \\
\hline & Jumlah & 1397 & 493 & 367 & 119 & 342 & 436 & 1413 & 3170 \\
\hline \multicolumn{2}{|c|}{ Cow Percentage (\%) } & - & 15,6 & 11,6 & 3,8 & 10,8 & 13,8 & 44,6 & 100 \\
\hline
\end{tabular}

Table 2, explains that the composition of the cattle population shows that of the 3170 head of cattle in Napis Village, the majority (44.6\%) were adult female cows; fostered by breeders to be able to get a calf through natural-mating with PO bulls in Napis Village. It was reported that Artificial Insemination had never been carried out in female cows in the Napis Village area. PO cattle naturally from mating, are then raised and reared by non-fattening (fattening).

Characteristics of People's Beef Cattle Business:-

Characteristics of smallholder beef cattle breeder business consist of components of the number of cattle, the status of mastery of cattle, land use and business income from cattle. The diversity of the score components of the characteristics of smallholder beef cattle business is presented in Table 3. 
Table 3:- Number of Cattle Cared, Cattle Mastery Status, and Land Area Mastered $(n=200)$.

\begin{tabular}{|c|c|c|c|c|c|}
\hline No. & Description & & Category & $\mathrm{n}$ & $(\%)$ \\
\hline \multirow[t]{5}{*}{1.} & \multirow[t]{5}{*}{ Number of Cows. } & 1 & $1(1 \mathrm{ST})$ & 21 & 10,5 \\
\hline & & 2 & $2-3(2-3 \mathrm{ST})$ & 89 & 44,5 \\
\hline & & 3 & $4-5(4-5 \mathrm{ST})$ & 44 & 22 \\
\hline & & 4 & $6-7(6-7 \mathrm{ST})$ & 40 & 20 \\
\hline & & 5 & $\geq 8(\geq 8 \mathrm{ST})$ & 6 & 3 \\
\hline \multirow[t]{5}{*}{2.} & \multirow[t]{5}{*}{ Cow mastery status. } & 1 & All cows belong to someone else & 25 & 12,5 \\
\hline & & 2 & 1 tail is one's own, the other is someone else's & 66 & 33 \\
\hline & & 3 & 1 tail of your own & 55 & 27,5 \\
\hline & & 4 & 2 of their own, the other of others & 29 & 14,5 \\
\hline & & 5 & $>2$ (all) own cows & 25 & 12,5 \\
\hline \multirow[t]{5}{*}{3.} & \multirow[t]{5}{*}{ Land use } & 1 & Not utilized & 5 & 2,5 \\
\hline & & 2 & Used for food crops & 50 & 25,0 \\
\hline & & 3 & Used for food crops and horticulture & 83 & 41,5 \\
\hline & & 4 & $\begin{array}{l}\text { Used for food crops, horticulture and grass }<0.25 \\
\text { hectares }\end{array}$ & 54 & 27,0 \\
\hline & & 5 & $\begin{array}{l}\text { Used for food crops and horticulture and grass }>0.30 \\
\text { hectares }\end{array}$ & 8 & 274,0 \\
\hline \multirow[t]{5}{*}{4.} & \multirow{5}{*}{$\begin{array}{l}\text { Average cattle } \\
\text { business income }\end{array}$} & 1 & There is but very small $=\mathrm{Rp}$. & 32 & 16,0 \\
\hline & & 2 & There are $<$ Rp. 3 million,- & 97 & 48,5 \\
\hline & & 3 & There are > Rp. 3.1 million, - to <Rp. 4 million,- & 37 & 18,5 \\
\hline & & 4 & There are $>$ Rp. 4.1 million up to $<$ Rp. 5 million,- & 20 & 10,0 \\
\hline & & 5 & There are> Rp. 5.1 million & 14 & 7,0 \\
\hline
\end{tabular}

Based on the results of a survey of 200 sample farmer household units, indicators of the number of cows that are kept, the status of mastery of cattle, and the area of land controlled by beef cattle farmer households indicate that:

1. Most of farm households (45\%) maintain 2 to 3 Livestock Units (ST).

2. The 'maro' working relationship (33\%) is taken by the farmer, besides raising a cow of their own (27.5\%).

3. Most (32.5\%) of farmers' households control an area of between $600-1000 \mathrm{~m} 2$

\section{Profile of Empowerment of Beef Cattle Farmers in Napis Village, Tambakrejo District, Bojonegoro} Regency:-

As long as the sustainable livelihoods approach to see people's livelihood conditions uses the concept of the Sustainable Livelihood Framework (SLF). SLF is a framework of thought in an effort to conceptualize the life and livelihood of a household holistically by taking into account the complexity of the possible relationship of various factors that exist with the problem of limitations and opportunities that exist for households in the condition of the location concerned to achieve household goals.

The framework of Sustainable Livelihood thinking in the research case ii is used as a measure of the level of empowerment of smallholder beef cattle farmers. This livelihoods approach is often referred to as a Pentagonal Asset (life asset), which consists of: 1. Human Capital (HC), 2. Natural Capital (NC), 3. Financial Capital (FC), 4. Physical Capital ( PC), and Social Capital (SC).

The livelihoods approach has first and foremost concern on Human Capital or people (people center) as important subjects. Human capital shows a person's ability to gain better access to their living conditions. As the most important asset in livelihood that enables one to carry out a livelihood strategy and achieve their livelihood goals, human capital is also needed to cultivate four other livelihood assets (DFID, 1999).

Natural Capital is a form of asset that comes from natural resources and the properties possessed by natural resources to be used by breeders' households to achieve the goals of rumatangga. Indicators of the Natural Capital condition of a farmer household can be developed based on ownership and characteristics of the mastery of natural resources in the farmer household, for example land resources, vegetation that can be utilized, livestock, water resources, relative soil fertility. The measurements are expressed in terms of weighted scores between 1 and 5 . 
Social Capital is an asset of the farmer household in the form of potentials arising from the process of social interaction between the farmer household and the wider community; This potential can be used by farmers households to achieve their goals. Social Capital can be developed by farmers households through networking and working relationships, both of which occur vertically in the form of patron-client relationships, as well as horizontal relationships based on mutual understanding to achieve similar interests. Apart from that, the participation of the farmer household in the farmer group can lead to positive formal collective attitudes that can be used as assets to achieve household goals. The measurements are expressed in terms of weighted scores between 1 and 5 .

Physical Capital consists of physical infrastructure as well as the nature of ownership and certain control status and can be used by farmers households in productive activities to achieve the objectives of the farmer's household, for example housing, road infrastructure, irrigation facilities, communication facilities, and vehicles . Physical Capital can also be in the form of tools that support the going on of a production process, for example cattle sheds, animal feed storage buildings and so on. The measurements are expressed in terms of weighted scores between 1 and 5 .

Based on observations from 200 farmer households, the scores of the five assets or capital are presented in Table 4.

Table 4:- Distribution of Pentagonal Asset Component Scores.

\begin{tabular}{|c|c|c|c|c|c|c|c|c|c|c|}
\hline \multirow{2}{*}{ Score } & \multicolumn{2}{|l|}{ Human Capital } & \multicolumn{2}{l|}{ Natural Capital } & \multicolumn{2}{c|}{ Financial Capital } & Physical Capital & \multicolumn{2}{c|}{$\begin{array}{c}\text { Social } \\
\text { Capital }\end{array}$} \\
\cline { 2 - 13 } & RT & \% & RT & \% & RT & \% & RT & \% & RT & \% \\
\hline Very High (5) & 48 & 24 & 21 & 10,5 & 14 & 7 & 9 & 4,5 & 13 & 6,5 \\
\hline Height (4) & 77 & 38,5 & 122 & 61 & 70 & 35 & 61 & 30,5 & 41 & 20,5 \\
\hline Medium (3) & 69 & 34,5 & 51 & 25,5 & 35 & 17,5 & 110 & 55 & 65 & 32,5 \\
\hline Low (2) & 6 & 3 & 6 & 3 & 80 & 40 & 15 & 7,5 & 74 & 37 \\
\hline Very Low (1) & 0 & 0 & 0 & 0 & 1 & 0,5 & 5 & 2,5 & 7 & 3,5 \\
\hline Average Score & \multicolumn{3}{|c|}{3,835} & \multicolumn{2}{|c|}{3,790} & \multicolumn{2}{|c|}{3,080} & \multicolumn{2}{|c|}{3,270} & 2,895 \\
\hline
\end{tabular}

Based on Table 4, the best living assets in the research location are Human Capital or the lowest human capital and social capital, with a score of 3,835 and 2,895. The good condition of human capital in Napis Village is supported by the formal education conditions of the farmer, the number of household members, the level of knowledge and skills in the field of animal husbandry, the condition of public health which is sufficient. The conditions of social interaction between farmer households and the wider community, horizontal networking and working relationships with fellow farmers and vertical relationships with stakeholders in the form of patron-client relationships have not been well established. The existence of farmer groups has not been able to generate positive formal collective attitudes that can be used as assets to achieve household empowerment goals.

Previous research has measured the level of household empowerment of beef cattle farmers using the concept of Pentagonal Aseet of Life. The current study of the level of empowerment is not only measured through the Pentagonal of Life Assets but also needs to be added to the external factors of the household that cannot be abandoned, namely the aspect of household resilience and dynamism. The score of the level of empowerment of farmers is the average score between Liveliood status, Household Resilience and Household Dynamic. Scores show categories between 1-5, showing categories from very low to very high. The various levels of household empowerment are presented in Table 5.

Table 5:- Diversity Level of Empowerment of Household Beef Cattle Farmers and Their Components.

\begin{tabular}{|c|c|c|c|c|c|c|c|c|}
\hline \multirow[t]{2}{*}{ Score } & \multicolumn{2}{|c|}{ Livelihood Status } & \multicolumn{2}{|c|}{ Household Resilience } & \multicolumn{2}{|c|}{ Household dynamism } & \multicolumn{2}{|c|}{$\begin{array}{l}\text { Level of Farmer } \\
\text { Empowerment }\end{array}$} \\
\hline & RT & $\%$ & RT & $\%$ & RT & $\%$ & RT & $\%$ \\
\hline Very High (5) & 12 & 6 & 10 & 5 & 51 & 25,5 & 13 & 6,5 \\
\hline Height (4) & 83 & 41,5 & 66 & 33 & 59 & 29,5 & 81 & 40,5 \\
\hline Medium (3) & 85 & 42,5 & 75 & 37,5 & 64 & 32 & 80 & 40,0 \\
\hline Low (2) & 19 & 9,5 & 48 & 24 & 26 & 13 & 25 & 12,5 \\
\hline Very Low (1) & 1 & 0,5 & 1 & 0,5 & 0 & 0 & 1 & 0,5 \\
\hline Average Score & \multicolumn{2}{|c|}{3,374} & \multicolumn{2}{|c|}{3,180} & \multicolumn{2}{|c|}{3,675} & \multicolumn{2}{|c|}{3,410} \\
\hline
\end{tabular}


Table 5, shows that among the 3 components of farmer empowerment, the household dynamics aspect has the highest average score of 3,675 following the livelihood status aspect of 3,374 and the last aspect of farmer household resilience is 3,180 . The distribution of scores and categories among the three aspects of household empowerment has a similar pattern. The distribution of the scores of the three components is in the medium and high categories. The Livelihood status component, around $84 \%$ is in the medium and high categories. The household resilience component of around $70.5 \%$ is in the medium and high category. The dynamics component of the household shows a somewhat different distribution, around $61.5 \%$ are between moderate and high, even around $87 \%$ are in the moderate to high or only 13 which has a low category. This shows that the dynamism conditions of household farmers in Napis Village, Tambakrejo District, Bojonegoro Regency are in a condition of good empowerment.

\section{Conclusion:-}

1. Sustainable livelihoods of the household of cattle breeders are not enough to be stated only by indicators of livelihoods-status consisting of 5 types of capital, namely: (1) Human Capital, (2) Natural Capital, (3) Financial Capital, (4) Physical Capital, and (5) Social Capital, but it also needs to include the resilience component of the farmer household and the dynamism component of the farmer household.

2. The sustainable livelihoods component of the people's beef cattle farmer household, the resilience component of the people's beef cattle farmer household, and the dynamic component of the people's beef cattle farmer household, together shape the empowerment of the people's beef cattle farmer household.

\section{Suggestion:-}

The development of the people's beef cattle agribusiness development for millennial young generation through increasing the empowerment of farmer households, needs to be supported by efforts to record and evaluate data dynamically on the status of farmer household empowerment status as a material to formulate priority priorities for further activities.

\section{References:-}

1. Badan Pusat Statistik , 2015, Analisis Rumah Tangga Usaha Peternakan di Indonesia Hasil Survei Rumah Tangga Usaha Peternakan 2014, Badan Pusat Statistik Jakarta.

2. Dahiri, 2016, Daging Sapi : Selamanya Impor atau Swasembada, Buletin APBN Edisi 12, Vol. I. Juni 2016, Pusat Kajian Anggaran Badan Keahlian DPR RI,, http://www.puskajianggaran.dpr.go.id

3. DFID (Department For International Development), 1999, Sustainable Livelihoods Guidance Sheets, The Department For International Development, Glasgow, United Kingdom.

4. Diwyanto, K., Inounu, I., Setioko, AR., Subandriyo, Kompiang, IP., Parede, L., Priyanti, A., Martindah, E., Saptati, RA., dan Nurhayati, IS., 2007, Pemberdayaan Masyarakat melalui Model Pengembangan Usaha Sapi Potong, Pusat Penelitian dan Pengembangan Peternakan, Badan Penelitian dan Pengembangan Pertanian, Bogor.

5. Mayulu, H., Sunarso , Sutrisno, CI., dan Sumarsono, 2010, Kebijakan Pengembangan Peternakan Sapi Potong di Indonesia , Jurnal Litbang Pertanian, 29(1), 2010, Jakarta. 